\title{
The Implementation Of Character Education In Indonesian Language Learning For Class Va Students At SD Inpres Parangrea, Bajeng District, Gowa Regency, South Sulawesi
}

\author{
Muhammad Akhir \\ The Indonesian Language and Literature Education Study Program of the Faculty of Teacher Training \\ and Education Universitas Muhammadiyah Makassar, Jl. Sultan Alauddin No.259, Makassar, Indonesia \\ 90221 \\ m.akhir@unismuh.ac.id
}

\begin{abstract}
This study aims to describe the implementation of character education and describe the inhibiting and supporting factors for implementing character education in Indonesian language learning in-class VA students at SD Inpres Parangrea, Bajeng District, Gowa Regency, South Sulawesi. This type of research is qualitative research. The results showed that the character values obtained from the students were religious, tolerant, disciplined, hard-working, independent, creative, curious, fond of reading, friendly/communicative, and responsible. With the implementation of character education in Indonesian language learning in-class VA students at SD Inpres Parangrea, Bajeng District, Gowa Regency, South Sulawesi, it can be carried out well and generally, taking actions such as 1). Learning planning, 2). Implementation of learning, 3). Learning evaluation. The inhibiting and supporting factors for the implementation of character education in Indonesian language learning for class VA students at SD Inpres Parangrea, Bajeng District, Gowa Regency, South Sulawesi. In comparison, the supporting factors of the implementation of character education in learning Indonesian in-class VA students at SD Inpres Parangrea, Bajeng District, Gowa Regency are 1). Teacher, 2). Character building at school.
\end{abstract}

Keywords: Character Education, Learning, Indonesian Language, Students

\begin{abstract}
Abstrak. Penelitian ini bertujuan untuk mendeskripsikan implementasi pendidikan karakter dan mendeskripsikan faktor penghambat dan pendukung implementasi pendidikan karakter dalam pembelajaran bahasa Indonesia pada peserta didik kelas VA di SD Inpres Parangrea Kecamatan Bajeng Kabupaten Gowa Sulawesi Selatan. Jenis penelitian ini adalah penelitian kualitatif. Hasil penelitian menunjukkan bahwa nilai karakter yang diperoleh dari peserta didik yaitu religius, toleransi, disiplin, kerja keras, mandiri, kreatif, rasa ingin tahu, gemar membaca, bersahabat/komunikatif, dan tanggung jawab. Dengan adanya implementasi pendidikan karakter dalam pembelajaran bahasa Indonesia pada peserta didik kelas VA di SD Inpres Parangrea Kecamatan Bajeng Kabupaten Gowa Sulawesi Selatan dapat terlaksana dengan baik dan secara garis besar yaitu dengan adanya tindakan seperti: 1). Perencanaan pembelajaran, 2). Pelaksanaan pembelajaran, 3). Evaluasi pembelajaran. Faktor penghambat dan pendukung implementasi pendidikan karakter dalam pembelajaran bahasa Indonesia pada peserta didik kelas VA di SD Inpres Parangrea Kecamatan Bajeng Kabupaten Gowa Sulawesi Selatan. Sedangkan faktor pendukung dari implementasi pendidikan karakter dalam pembelajaran bahasa Indonesia pada peserta didik kelas VA di SDI Parangrea adalah 1). Guru, 2). Pembinaan karakter di sekolah
\end{abstract}

Kata Kunci: Pendidikan Karakter, Pembelajaran, Bahasa Indonesia, Peserta Didik 


\section{INTRODUCTION}

Currently, Indonesia is experiencing moral decadence (Kanji et al., 2019b) (Nursalam et al., 2020), multidimensional crisis, degradation of social care (Kanji et al., 2020a), demoralization of religious character (Suardi et al., 2021) (Suardi et al., 2021) (Nur et al., 2021) to the point that behaviors that take lives often occur in Indonesia. Moral degradation that occurs in the nation's children has an effect on the progress of the Indonesian nation, so the problem of moral degradation must be quickly addressed.

One of the steps that can be taken to solve problems and deviations that exist in Indonesia is through character education (Suardi et al., 2018).

Character is the value of human behavior related to oneself, fellow humans, environment, and nationality to God Almighty, which is manifested in thoughts, feelings, behavior from all aspects of life. So, character education plays an essential role in shaping the nation's generation (Akhir \& Junaedi, 2021). Education develops abilities and must shape the character and civilization of a more dignified nation because every child of the country can be a character who can distinguish them from other people who have no character (Big Indonesian Dictionary 1990).

The process of character building at every level of education must aim to form a nation of character that comes from faith and piety to God Almighty and based on Pancasila (Narwanti, 2012).

Education based on character values in accordance with the religion and culture of the nation can be done through the use of good language because language is proven to have a role in shaping the character of the nation's children (Akhir, 2017b) (Akhir, 2016a).

Character building at the education level involves language to communicate to students and form a character culture in schools. That is one reason language is an essential element of culture, because cultural change is one of them because of the role of language. Language as a communication tool in character building is not only a sound. Still, it must have a symbol or symbol (Keraf, 1997) that is meaningful for students to improve their communication skills (Surianto et al., 2020).

One of the languages that have an essential role in character education is Indonesian; apart from being a national language, it is also the identity of the Indonesian nation. So that character education and Indonesian is an integrity in the learning process at school.

Character education and the Indonesian language learning process have a relationship with character education contained in the Indonesian language learning process. Conversely, in Indonesian language learning, character education values can be obtained, including the character of discipline 
or responsibility (Akhir, 2016b) (Akhir, 2017b). The formation of the character of students can be done through the learning process in every subject taught by subject teachers at school (Suardi et al., 2019)

Learning Indonesian at the elementary school level includes four competencies: listening, speaking, reading (Akhir \& Marwiah, 2021) and writing (Akhir, 2016b).

Character education in Indonesian language learning in elementary schools is to form the strong character of students so that students have an awareness of the importance of character values in the world of education, as well as in social life because if character education is not formed early, it will be challenging to provide character strengthening at a higher level.

One elementary school with a school vision to foster character is SD Inpres Parangrea, Gowa Regency. The vision of the Parangrea Presidential Instruction in Gowa Regency is to be superior, intelligent, have character, and care about the environment. This vision will be pursued by fostering a spirit of excellence for all school members, creating an effective learning process, improving the quality of highly competitive graduates, developing students' personalities with national character, creating a clean and green and beautiful and healthy school environment and realizing environmental conservation. Around school. Collaboratively developing the character of students from all components in the school (Suardi, Agustang, et al., 2020) as a way to strengthen the character education process in schools (Suardi, Nursalam, et al., 2020)

Based on the vision and mission, the Indonesian language learning process is integrated with character values to achieve the school's vision, especially in the VA class, which is the object of study in the research.

\section{RESEARCH METHODS}

This research was a type of qualitative research, trying to dig up information from interviews, field notes, and documents such as photos, videos, books, journals or important notes related to character education in learning Indonesian at SD Inpres Parangrea, Bajeng District, Gowa Regency.

The focus of the research is the implementation of character education through Indonesian language subjects. In contrast, the subjects in this study were class VA teachers, school principals, curriculum administrator and students of class VA. This research was conducted in the academic year 2020/2021, which started on June 08-June 26, 2021. This research was carried out at SD Inpres Parangrea in Gowa Regency, which was located at Jl. Taipa Tassampea, Panyangkalang, Bajeng District, Gowa Regency, South Sulawesi Province.

Data collection techniques were through observation of ongoing activities, interviews through direct oral questions and answers related to the research focus, and 
various references associated with research problems.

\section{DISCUSSION}

The character values at SD Inpres Parangrea, Bajeng District, Gowa Regency are as follows:

\begin{tabular}{|c|c|}
\hline $\begin{array}{l}\text { Character } \\
\text { Value }\end{array}$ & Indicator \\
\hline Religious & $\begin{array}{l}\text { - Pray before starting the } \\
\text { lesson } \\
\text { - The teacher teaches them } \\
\text { always to be grateful for } \\
\text { what they have received } \\
\text { from Allah SWT. }\end{array}$ \\
\hline Tolerance & $\begin{array}{l}\text { - Teachers provide the same } \\
\text { service to all students } \\
\text { without distinguishing one } \\
\text { another } \\
\text { - Appreciate the friends } \\
\text { opinion }\end{array}$ \\
\hline Discipline & $\begin{array}{l}\text { - Collect assignments on } \\
\text { time }\end{array}$ \\
\hline Hard work & $\begin{array}{ll}\text { - Doing } & \text { tasks } \\
\text { diligently/sincerely }\end{array}$ \\
\hline $\begin{array}{l}\text { independe } \\
\mathrm{nt}\end{array}$ & $\begin{array}{l}\text { - Do the homework } \\
\text { independently }\end{array}$ \\
\hline Creative & $\begin{array}{l}\text { - Creating learning } \\
\text { situations that can foster } \\
\text { creative thinking and } \\
\text { acting - } \\
\text { - Giving challenging } \\
\text { assignments so that } \\
\text { students' work and creative } \\
\text { ideas emerge }\end{array}$ \\
\hline Curiosity & $\begin{array}{l}\text { - Creating a class } \\
\text { atmosphere that invites the } \\
\text { students "curiosity o }\end{array}$ \\
\hline $\begin{array}{l}\text { Like } \\
\text { read }\end{array}$ & $\begin{array}{l}\text { - Read the material given by } \\
\text { the teacher }\end{array}$ \\
\hline $\begin{array}{l}\text { friendly/ } \\
\text { Communic } \\
\text { ative }\end{array}$ & $\begin{array}{l}\text { - Be friendly to friends and } \\
\text { teachers }\end{array}$ \\
\hline $\begin{array}{l}\text { Responsibi } \\
\text { lity }\end{array}$ & $\begin{array}{l}\text { Carry out the tasks assigned } \\
\text { by the teacher }\end{array}$ \\
\hline
\end{tabular}

Based on the research that has been done, it can be seen that in SD Inpres Parangrea, Bajeng District, Gowa Regency, especially class VA, character education is a process of forming the daily values of students in the learning process, especially in Indonesian subjects.

\section{Implementation of Character Education in} Indonesian Language Learning for Class V Students at SD Inpres Parangrea, Bajeng

\section{District, Gowa Regency}

\section{Lesson Planning}

Learning Plan, Character education is the inculcation of daily values to students in the learning process. Through interviews, most of the subjects said that character education in learning Indonesian at SD Inpres Parangrea, Bajeng District, Gowa Regency started from how the teacher taught.

The teacher plans the implementation of character education in learning through making syllabus and lesson plans. The syllabus is usually made every new semester. The teacher prepares the implementation of character education for students by including the character values to be achieved in the syllabus and learning implementation plans.

Efforts that have been made at SD Inpres Parangrea, Bajeng District, Gowa Regency, for students of class VA character education are carried out in the daily lives of students in class such as through lectures by teachers and providing examples of character implementation so that as educators must 
provide examples of which characters should be included. Instilled in themselves, then reviewing students' daily lives in implementing character values in each lesson, because in Indonesian language learning, there are character indicators that are expected to be achieved by students listed in learning tools such as syllabus and lesson plans.

\section{Learning Implementation}

The implementation of Indonesian language learning for students at SD Inpres Parangrea, Bajeng District, Gowa Regency actualizes character values through learning materials containing religion, friendly/communicative, and tolerance.

There are several efforts made by teachers of Indonesian subjects, specifically in-class VA, to develop the character of students, namely:

a. The Indonesian language teacher starts each lesson by praying.

b. Indonesian language teachers always remind students to be grateful for what they have got from Allah,

c. Teachers of Indonesian subjects teach to have tolerance towards their friends.

Indonesian language learning has four essential aspects, namely listening, speaking, writing, and reading, which is very influential for students' character education. For example, students are taught to communicate well and politely to their opponents in the speaking aspect. From there, Indonesian language teachers can instill character in students according to Competency Standards and Basic Competencies indicators. The character implementation education program at the Parangrea Inpres Elementary School was carried out correctly in accordance with what was taught by the head of the service. All aspects of character education were carried out well in each subject. Some indicators were expected for students, usually learning tools such as the syllabus and lesson plan.

\section{Learning Evaluation}

Assessment of character education is carried out through giving questions to reveal the ability of students to practice character values, especially in learning Indonesian, such as reading, writing, listening and speaking. Evaluation of character education in schools is critical to determine the achievement of students' character values (Kanji et al., 2019a)

The character values generated from reading advertisements, namely curiosity and love to read, are following how students read advertisements carefully. The ability to read is primarily determined by the teacher's strategy in teaching (Akhir, 2017a). The character values resulting from writing advertisements are hard work and responsibility. They have great enthusiasm and commitment in completing the task of writing advertisements given by the teacher. The character values generated from observations are tolerance. They observe their friends who are reading advertisements and respect the opinions of other friends. 
The achievement of students in learning can be proven by looking at the value of students' assignments in each language skill, especially in the aspects of listening, speaking, writing and reading. As educators in implementing character education in Indonesian language learning, they have developed character education well. This has been tested based on the value of character education that already exists and the addition of character indicators in accordance with the conditions needed by students at the Inpres Parangrea Elementary School, Bajeng District, Gowa Regency. Character education in elementary schools has to support and inhibit factors in the implementation process (Kanji et al., 2020b).

Factors inhibiting the implementation of character education in learning Indonesian in class VA students at SD Inpres Parangrea, Bajeng District, Gowa Regency.

\section{Facilities and infrastructure}

Every school needs adequate facilities and infrastructure such as libraries, computer laboratories, and also learning media that can support the learning process, such as maps, human frameworks, tutorial media (Amin et al., 2021), service advertisements (Surianti et al., 2019) as well as learning media based on local wisdom (Suardi \& Syarifuddin, 2018). So that it requires teacher innovation and creativity in providing learning media that are in accordance with the characteristics of students (Israpil \& Suardi, 2021). To implement character education in Parangrea Inpres, elementary schools still need good facilities and infrastructure because good facilities and infrastructure will make the learning process go well, such as the existence of a library, prayer room, and learning media that support the learning process. Facilities and infrastructure can support the learning process for the better and the implementation of character education.

\section{Technological Development}

Technological developments are very influential for education, especially in children's character education. Indonesian language teachers can get various kinds of information easily and quickly through the internet, cellphones, laptops, etc. However, many students still misuse the technology so that the implementation of character education is hampered at the Parangrea Presidential Instruction Elementary School. The use of gadgets has a massive impact on students. When students are assigned to study at home, sometimes when learning online, they hold their cellphones. More often, they update status, check social media rather than pay attention to the learning process guided by the teacher, so gadgets play a factoring role. Most significant influence on the learning process of students and build character.

\section{Students}

Students also determine the quality and quantity in the school. This includes the Inpres Parangrea Elementary School, Bajeng 
District, Gowa Regency. There are still many lazy children who know that it is an obstacle, but it is not an obstacle to give directions so that children can carry out character education. Childhood is a time of play, but Indonesian language teachers as educators must also direct children to positive things.

\section{Covid-19}

Online learning that is being carried out at this time caused by Covid-19 influences the implementation of character education for students because learning is being carried out at this time. After all, it is constrained that the last two years we have been exposed to covid 19 so that it also affects the character of students who were initially diligent and then eroded, they have started to be lazy because it is constrained by the learning process that can no longer be implemented in schools. Learning done at home or online influences the implementation of character education for students, especially in SD Inpres Parangrea, Bajeng District, Gowa Regency.

Factors Supporting the implementation of character education in learning Indonesian in class VA students at SD Inpres Parangrea, Bajeng District, Gowa Regency.

\section{Teacher}

Every school, especially in SD Inpres Parangrea, Bajeng District, Gowa Regency, teachers have a significant impact on the formation of students' character. Teachers also have a big responsibility to build the character of students. Because students' character can be formed with the help of other people or interaction with the people around them. In every lesson, there must be interaction between the Indonesian language teacher and students. In addition, the supporting factors in terms of writing and speaking skills of students include the skills of students can improve when continuously honed both by teachers as educators and by peers, Indonesian language teachers are given a kind of task to practice speaking skills and writing skills. Students at SD Inpres Parangrea, Bajeng District, Gowa Regency who can help students in implementing character education by being given a kind of task to train students' speaking and writing skills.

\section{Character building at school}

At SD Inpres Parangrea, Bajeng Subdistrict, Gowa Regency, character building for students has been carried out in daily life and the education of students in the class. The Indonesian language teacher gives lectures and examples of how in the implementation of character, the Indonesian language teacher as educators provides examples of which is included in the performance of the nature then review in the student's daily life to implement it or not. In addition, before starting learning, they always say hello and greet and shake hands with the Indonesian language teacher when they meet. The students are happy with learning Indonesian because the teacher is Indonesian and interested in the material to be taught. 


\section{CONCLUSION}

Based on the results of research that has been carried out by researchers regarding the implementation of character education in Indonesian language learning in-class VA students at the Parangrea Inpres Elementary School, the researchers can conclude that the implementation of character education in Indonesian language learning at Parangrea Inpres Elementary School is carried out through planning, implementation, and evaluation. Class VA teachers at SD Inpres Parangrea, Bajeng District, Gowa Regency conduct lesson plans by instilling character values that students will achieve through the syllabus and lesson plans.

The inhibiting factors for the implementation of character education at SD Inpres Parangrea, Bajeng District, Gowa Regency are the lack of facilities and infrastructure, technological developments that students misinterpret, students who are lazy to know, and online learning caused by the presence of covid 19. While the supporting factors for implementation character education in Indonesian language learning for class VA students at SD Inpres Parangrea, Bajeng District, Gowa Regency, namely teachers who always educate their students and also character building carried out by the school.

\section{REFERENCES}

[1] Akhdiah, Sabarti, Dkk. (1992). Bahasa Indonesia 1. Jakarta: Departemen Pendidikan dan Kebudayaan
[2] Akhir, Muhammad dan Junaedi. (2021). Budaya Karakter di Sekolah Dasar. Surabaya: CV. Kanaka Media

[3] Akhir, M. (2017a). Penerapan Strategi Belajar Reciprocal Teaching terhadap Kemampuan Membaca pada Siswa SD. Indonesian Journal of Primary Education, 1(2), 30. https://doi.org/10.17509/ijpe.v1i2.9313

[4] Akhir, M. (2017b). PENGEMBANGAN MATERI AJAR BAHASA INDONESIA BERBASIS KARAKTER [Universitas Negeri Makassar]. In Solid State Ionics. http://linkinghub.elsevier.com/retrieve/pii/S0 $167273817305726 \% 0$ Ahttp://dx.doi.org/10.1 038/s41467-017-01772-

1\%0Ahttp://www.ing.unitn.it/ luttero/laborat oriomateriali/RietveldRefinements.pdf $\% 0 \mathrm{Ah}$ ttp://www.intechopen.com/books/spectrosco pic-analyses-developments-an

[5] Akhir, M. (2016a). PENGEMBANGAN MATERI AJAR BAHASA INDONESIA BERBASIS KARAKTER PADA MAHASISWA UNIVERSITAS MUHAMMADIYAH MAKASSAR. In Juhansar \& T. Widodo (Eds.), Proceedings of the 5th International Seminar on Quality and Affordable Education (Issue December, pp. 663-674). Universitas Teknologi Yogyakarta.

[6] Akhir, M. (2016b). PENGEMBANGAN MATERI AJAR BAHASA INDONESIA BERBASIS KARAKTER PADA MAHASISWA UNIVERSITAS MUHAMMADIYAH MAKASSAR. International Seminar on Quality and Affordable Education | ISQAE, 663-674. www.uty.ac.id

[7] Akhir, M., \& Marwiah, M. (2021). Barrett Taxonomy Reorganization To Improve Students' Intensive Reading Ability. Journal of Educational Science and Technology (EST), 7(1), 76-83. https://doi.org/10.26858/est.v7i1.16417

[8] Amin, M., Rahim, A. R., \& Akhir, M. (2021). KEEFEKTIFAN MEDIA VIDEO TUTORIAL TERHADAP PENINGKATAN KETERAMPILAN MENULIS TEKS PROSEDUR SISWA KELAS VI SDN 143 INPRES LEKO KEEFEKTIFAN MEDIA VIDEO TUTORIAL TERHADAP PROSEDUR SISWA KELAS VI SDN 143 INPRES LEKO. JRIP: Jurnal Riset Dan Inovasi Pembelajaran, 1(2), 71-81.

[9] Israpil, \& Suardi. (2021). The Innovation and Creativity of Religious Moderation Learning Through Sociology Learning and Pancasila 
and Citizenship Education in Public Schools and Madrasas Gorontalo City. JED (Jurnal Etika Demokrasi), 6(2), 232-242. https://doi.org/https://doi.org/10.26618/jed.v $6 \mathrm{i} 1.4692$

[10] Kanji, H., Nursalam, N., Nawir, M., \& Suardi, S. (2019a). Evaluasi Integrasi Pendidikan Karakter dalam Pembelajaran Ilmu Pengetahuan Sosial di Sekolah Dasar. JED (Jurnal Etika Demokrasi), 4(2), 56-63. https://doi.org/10.26618/jed.v4i2.2386

[11] Kanji, H., Nursalam, N., Nawir, M., \& Suardi, S. (2020a). INTEGRATION OF SOCIAL CARE CHARACTERS AND MORAL INTEGRATIF ON SOCIAL SCIENCE LESSONS IN ELEMENTARY SCHOOL. AL-ISHLAH: Jurnal Pendidikan, 12(2), 413-427. https://doi.org/10.35445/alishlah.v12i2.260

[12] Kanji, H., Nursalam, Nawir, M., \& Suardi. (2019b). Model Integrasi Pendidikan Karakter dalam Pembelajaran Ilmu Pengetahun Sosial di Sekolah Dasar. Jurnal Pendidikan Dasar Perkhasa , 5(2), 104-115. https://doi.org/10.31932/jpdp.v5i2.458

[13] Kanji, H., Nursalam, Nawir, M., \& Suardi. (2020b). Supporting and Inhibiting Factors of Character Education in Learning Social Studies at Primary Schools. JED (Journal of Etika Demokrasi), 5(1), 1-14. https://doi.org/10.26618/JED.V5I1.2966

[14] Keraf, Gorys. 1997. Komposisi: Sebuah Pengantar Kemahiran Bahasa. Ende Flores: Nusa Indah

[15] Kurniawan, Syamsul. 2016. Pendidikan Karakter Konsepsi \& Implementasi Secara Terpadu Di Lingkungan Keluarga, Sekolah, Perguruan Tinggi \& Masyarakat. Yogyakarta: Ar-Ruzz Media

[16] Nur, R., Suardi, Nursalam, \& Kanji, H. (2021). Integrated Model of Character Education Development Based on Moral Integrative to Prevent Character Value Breaches. AL-ISHLAH: Jurnal Pendidikan, 13(1), 107-116. https://doi.org/10.35445/alishlah.v13i1.272

[17] Narwanti, Sri. 2012. Pendidikan Karakter Pengintegrasian 18 Nilai Pembentuk Karakter Dalam Mata Pelajaran. Yogyakarta: Familia

[18] Nursalam, Nawir, M., Suardi, \& Kanji, H. (2020). MODEL PENDIDIKAN KARAKTER PADA MATA PELAJARAN ILMU PENGETAHUAN SOSIAL DI SEKOLAH DASAR (Vol. 1). CV. AA. RIZKY. https://books.google.co.id/books?hl=id\&lr= \&id=8tUKEAAAQBAJ\&oi=fnd\&pg=PA63
$\& d q=$ buku + suardi + nursalam + pendidikan + ka rakter\&ots $=1 \mathrm{~A}-\mathrm{-}$

g2fQs4\&sig=zVhj4kYePdGJVf09G419nxFsH4\&redir_esc $=y \# v=$ onepage $\& \mathrm{q}=$ buku suardi nursalam pendidikan karakter\& $\mathrm{f}=$ false

[19] Parera, J.D. (1996). Pedoman Kegiatan Belajar Mengajar Bahasa Indonesia. Jakarta: Gramedia

[20] Sugono, Dedy. (2003). Buku Praktis Bahasa Indonesia 2. Jakarta: Pusat Bahasa Departemen Pendidikan Nasional

[21] Suardi, Agustang, A., \& Sahabuddin, J. (2020). MODEL KOLABORASI SOSIAL PENDIDIKAN KARAKTER DI SEKOLAH SWASTA KECAMATAN BISSAPPU KABUPATEN BANTAENG. PROSIDING SEMINAR DAN DISKUSI PENDIDIKAN $D A S A R$, $1-11$. http://journal.unj.ac.id/unj/index.php/psdpd/a rticle/view/17769

[22] Suardi, Nursalam, \& Hasnah, K. (2021). The Integration Model of the Development of Student Religious Character Education Based on Integrative Morals in Higher Education. ... (Journal of Etika Demokrasi), $6(1)$ 149-162. https://jurnal.unismuh.ac.id/index.php/jed/art icle/view/4692

[23] Suardi, Nursalam, \& Kanji, H. (2020). PENGUATAN PENDIDIKAN KARAKTER: BERBASIS INTEGRATIF MORAL DI PERGURUAN TINGGI (Vol. 1). CV. AA. RIZKY.

https://books.google.co.id/books?hl=id\&lr= \&id=DOADEAAAQBAJ\&oi=fnd\&pg=PA1 $\& d q=$ buku + suardi + nursalam + pendidikan $+k a$ rakter\&ots $=\mathrm{aL} 1 \mathrm{dBe} 9 \mathrm{Ue} 3 \&$ sig $=\mathrm{oMu} 7 \mathrm{hsupR}$ OlXcDncIso8LdgI_Oc\&redir_esc $=\mathrm{y} \# \mathrm{v}=$ onep age \&q=buku suardi nursalam pendidikan karakter\&f=false

[24] Suardi, S., Herdiansyah, H., Ramlan, H., \& Mutiara, I. A. (2019). Implementasi Pendidikan Karakter Melalui Mata Pelajaran Pendidikan Kewarganegaraan di SMA Jaya Negara Makassar. JED (Jurnal Etika Demokrasi), 4(1), 22-29. https://doi.org/10.26618/jed.v4i1.1983

[25] Suardi, S., Megawati, M., \& Kanji, H. (2018). Pendidikan Karakter di Sekolah (Studi Penyimpangan Siswa di Mts Muhammadiyah Tallo). JED (Jurnal Etika Demokrasi), 3(1), 75-84.

https://doi.org/10.26618/jed.v3i1.1979

[26] Suardi, \& Syarifuddin. (2018). Penerapan Model Pembelajaran Saintifik Approacd Berbasis Media Pembelajaran Kearifan Lokal pada Mata Kuliah Dasar-Dasar 
Sosiologi dalam Membangun Karakter dan Meningkatkan Hasil Belajar Mahasiswa Pendidikan Sosiologi Universitas Muhammadiyah Makassar. JED (Jurnal Etika Demokrasi), 3(2), 75-85. https://doi.org/10.26618/jed.v3i2.1627

[27] Surianti, Akhir, M., \& Nojeng, A. (2019). Tindak Tutur Ilokusi Sebagai Media Penyampaian Pesan Sosial Pada Iklan Layanan Masyarakat. Celebes of Linguistics Journal, 1(2), 11-18. http://journal.lldikti9.id/linguistik

[28] Surianto, Syamsuri, A. S., \& Akhir, M. (2020). Pembelajaran Bahasa Indonesia Dengan Teknik Permainan Kelompok Siswa Kelas V Di Sdn 110 Lagoari. Edumaspul: Jurnal Pendidikan, 4(1), 88-97. https://ummaspul.ejournal.id/maspuljr/article/view/211

[29] Tim Penyusun Kamus. (1990). Kamus Besar Bahasa Indonesia. Jakarta: Balai Pustaka.

[30] Wibowo, Wahyu. (2007). Menjadi Penulis Dan Penyunting Sukses. Jakarta: Bumi Aksara 